Faunal make- up, host $r$ ange and i nf est at $i$ on $r$ ate of weevils and tephritid flies associated with fl ower heads of the thi stle Cirsi um (Car dueae : Ast ar aceae) in Japan

\begin{tabular}{|l|l|}
\hline 著者 & Nakamur a Aki nor i , Nakamur a Koj i \\
\hline $\begin{array}{l}\text { j our nal or } \\
\text { publ i cat i on t i t l e }\end{array}$ & Ent ombl ogi cal sci ence \\
\hline vol une & 7 \\
\hline number & 4 \\
\hline page r ange & $295-308$ \\
\hline year & 2004 12-25 \\
\hline URL & ht t p: //hdl . handl e. net /2297/12295 \\
\hline
\end{tabular}




\title{
Faunal make-up, host range and infestation rate of weevils and tephritid flies associated with flower heads of the thistle Cirsium (Cardueae: Astaraceae) in Japan
}

\author{
Akinori NAKAMURA and Koji NAKAMURA \\ Laboratory of Ecology, Faculty of Science, Kanazawa University, Kakuma, Kanazawa, Japan
}

\begin{abstract}
From 1988 to 1998, we collected flower heads of 39 thistle taxa (35 taxa of Cirsium, one species each of Breea, Synurus, Saussurea and Arctium; Cardueae; Astaraceae) in Japan, mainly from Hokuriku and other parts of central Honshu, and kept them in the laboratory to breed weevils and tephritid flies, the core fauna. We report the faunal make-up, host plants, geographic distribution and the attack levels of the insects. Results indicated that (i) three Larinus species (Curculionidae) and three species of tephritid flies (Tephritis, Urophora and Xyphosia) comprised the core fauna; (ii) two insect species belonging to the same taxonomic group (either Curculionidae (Larinus) or Tephritidae) tended to use different host plant species; (iii) two sympatric Larinus species (L. latissimus and L. meleagris) segregated the host plants seasonally in central Honshu (Cirsium blooming in spring and autumn, respectively); and (iv) two tephritid fly species, Xyphosia punctigera and Urophora sachalinensis, segregated geographically (the former on the Japan Sea side and the latter on the Pacific Ocean side). In comparison with their European counterparts, the weevils and tephritids of the Japanese Cirsium are characterized by a lower species richness and a lower degree of specialization in usage of the thistle flower heads, with gall-formers being distinctly under-represented, and callus tissue-feeders being absent. This reflects the fact that Japanese thistles are so closely related that hybridization frequently occurs, and also that the thistles have had a short history of interaction with the insects since the thistles' arrival in Japan.
\end{abstract}

Key words: Curculionidae, insect fauna, insect-plant relationship, Japanese thistle flower head, Tephritidae.

\section{INTRODUCTION}

Thistles, members of the tribe Cardueae (Astaraceae), are annual or perennial herbaceous plants that occur throughout the Holarctic region from the Mediterranean to East Asia and the Nearctic region (Bremer 1994). All structures of the Cardueae (e.g. roots, stems, leaves, buds and flower heads) are attacked externally as well as internally by a group of phytophagous insects specific to each structure (Zwölfer 1965, 1973; Zwölfer et al. 1971; Redfern 1983; Briese et al. 1994). The this-

Correspondence: Akinori Nakamura, Laboratory of Ecology, Faculty of Science, Kanazawa University, Kakuma, Kanazawa, Ishikawa, 920-1192 Japan.

Email: nakaaki@nihonkai.kanazawa-u.ac.jp

Received 12 March 2003; accepted 10 March 2004. tle flower head is a rich source of food, packed with achenes, and contains the most varied, specific and best known insect fauna of any part of the plant (Redfern 1983; Zwölfer 1988). The larvae of several herbivorous groups live here - tephritid flies, weevils and moths together with their parasitoids, and constitute ecological microsystems that offer opportunities to study a variety of ecological and entomological subjects (Zwölfer 1979, $1987,1988)$ as follows.

1 The adaptation of phytophagous insects to thistle hosts; for example, phenological synchronization (Romstöck-Völkl \& Wissel 1989; Straw 1989a,b, 1991), morphological adaptation to flower head size (ovipositor length of tephritids: Zwölfer 1982, 1987; rostrum length of weevils: Zwölfer \& Brandl 1989) and biotype formation (Zwölfer \& Romstöck-Völkl 1991; Romstöck-Völkl 1997). 
2 Interspecific interactions among the insects in the flower head (Zwölfer 1979, 1994; Berube 1980).

3 Comparison of insect fauna of European thistle species, which were introduced into North America and have become agricultural weeds, between the original and introduced regions to search for pest control agents (Goeden 1974; Goeden \& Ricker 1986a).

4 Major determinant of thistle insect diversity, such as the regional and local species richness of the host thistles and biogeographic history of the Cardueae (Zwölfer 1985).

According to Webb (1976), the Cardueae originated in the Mediterranean and Western Asia where they are most diverse, having 40 genera. From this center, they spread throughout Europe, parts of North Africa and much of Asia, thereafter reaching North America via the Bering Strait land connection (Small 1919). Reflecting this history, the diversity of the tribe decreased from the Mediterranean and Western Asia to North America (Zwölfer \& Romstöck-Völkl 1991): in Japan, it is represented by nine genera (Kadota 1995), while in North America, by only three genera (Bremer 1994). In contrast, the genus Cirsium Mill. has diversified into more than 60 species in Japan, as many as in all of Europe (Kitamura 1937; Kadota 1995), and into approximately 90 species in North America. In Japan, the species of this genus are mostly endemic. They are often difficult to identify to species not only because different species are often morphologically similar and/ or morphologically variable within a population, but also because they easily hybridize. Such situations have prevented us from carrying out studies of insect fauna associated with the thistles, despite these studies being promising.

Since 1988, we have collected thistle flower heads mainly from the Hokuriku district and other areas of central Honshu, the main island of Japan, to study the insect fauna in them. The present paper provides (i) a list of the weevils (Coleoptera: Cucurlionidae) and tephritid flies (Diptera: Tephritidae) obtained from the thistle flower heads, the core fauna associated with the flower heads; (ii) the degree of flower head damage by these insects; and (iii) their geographic distribution. From these data, overlap and/or segregation of host plant usage (thistle species, flowering seasons and geographic distribution) among the insects and the degree of their interactions have been analyzed. Finally, the insect fauna on the Japanese thistle flower head is compared with that in Europe and in North America in terms of species richness and specialization of guild structure.

\section{MATERIALS AND METHODS}

\section{Japanese Cirsium}

From 1988 to 1990 and from 1993 to 1998, thistle flower heads of the genus Cirsium (35 taxa consisting of 28 species, one subspecies and six varieties), together with those of the genera Breea Less., Synurus Iljin., Saussurea DC. and Arctium L. (one species each) (Table 1), were collected during the flowering seasons at 163 sites from Hokkaido to Okinawa, concentrating on central Honshu (Figs 1,2). Of the thistles studied, C. japonicum Fisch. ex DC., which is widespread in Honshu, Shikoku and Kyushu, and C. brevicaule A. Gray in Okinawa bloom in spring (hereafter termed 'spring-blooming' species). These two species are the only spring-blooming species in Japan. The flowering seasons of all other thistles collected in Honshu and Kyushu are from late summer to late autumn ('autumnblooming' species). Flowering seasons of nine thistle species (three genera) collected in Hokkaido were from July to September: we treated these as autumn-blooming species in this study.

\section{Collection of flower heads and insects}

In this study, a group of flower heads collected at one time from the same thistle population is referred to as a 'sample'. The attack rate (AR) was calculated for samples with more than 100 flower heads (these are referred to as 'effective samples'), except for those specifically mentioned. Table 1 shows the total number of flower heads collected (NF) and the number of effective samples for each thistle species. A large number of samples were gathered from central Honshu (e.g. C. japonicum, 40 samples from 35 sites, $\mathrm{NF}=9718$; C. matsumurae Nakai, 24 samples from 18 sites, $\mathrm{NF}=5692$; C. suzukaense Kitam., 14 samples from 14 sites, $\mathrm{NF}=4189$; and C. kagamontanum Nakai, 13 samples from three sites, $\mathrm{NF}=4143$ ). For the species distributed in other regions, only a few samples were obtained (e.g. one sample for C. uetsuense Kitam., C. congestissimum Kitam. and C. bitchuense Nakai, $\mathrm{NF}=152,247$ and 345, respectively). For the thistles with large NF, the number of flower heads collected per sample $(n f)$ varied greatly among the samples (e.g. C. japonicum, 39-665; C. matsumurae, 28-854). The number of effective samples of each thistle species varied from 0 to 35 (Table 1).

\section{Rearing of flower head insects}

Collected flower heads were brought back to the laboratory and were kept in insect nets $10.5 \mathrm{~m}$ in 
Figure 1 Location of Cirsium sampling sites. (a) $\triangle$, C. nipponicum; $O$, C. matsumurae; $\square$, C. yezoense; $\nabla$, C. ashiuense; $\diamond$, C. microspicatum var. kiotoense; $\boldsymbol{\Delta}$, C. kagamontanum; $\mathbf{\square}$ C. purpuratum; $\boldsymbol{\nabla}$, C. buergeri; $\bullet$, C. nipponicum var. yoshinoi; @, C. suzukaense. (b) 1, C. kamtschaticum; 2, C. heiianum; 3, C. vulgare; 4, C. kamtschaticum subsp. boreale; 5, C. alpicola; 6, C.pendulum; 7, C. oligophyllum; 8, C. dipsacolepis; 9, C. amplexifolium; 10, C. uetsuense; 11, C. microspicatum; 12, C. matsumurae var. pubescens; 13, C. inundatum; 14, C. matsumurae var. dubium; 15, C. otayae; 16, C. norikurense; 17, C. comocum var. yatsugatakense; 18, C. maritimum; 19, C. congestissimum; 20, C. bitchuense var. manisaense; 21, C. bitchuense; 22, C. sieboldii; 23, C. suffultum; and 24, C. brevicaure.
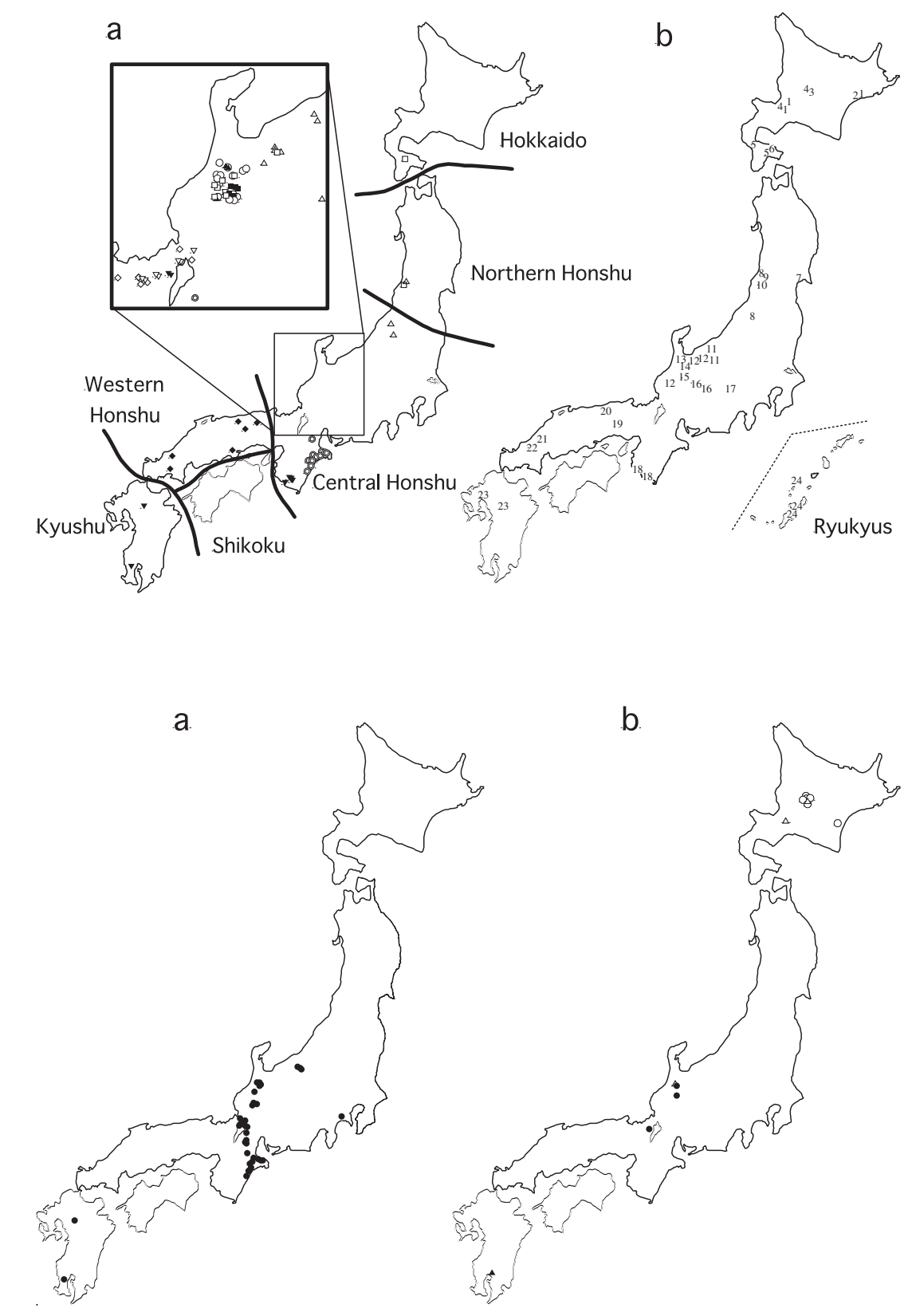

Figure 2 Location of sampling sites. (a) Cirsium japonicum. (b) $\triangle$, Arctium lappa; O, Breea setosa; $\mathbf{\Delta}$, Saussurea japonica; and $\bullet$, Synurus pungens. diameter $\times 0.7 \mathrm{~m}$ in length) to obtain adults, which emerged the following autumn and the following spring from the samples collected in spring and autumn, respectively. The total number of individuals in each insect species that emerged from a sample $(n e)$ was recorded.

\section{Total number of insect individuals that emerged from a single flower head}

The total number of insect individuals that emerged from a single flower head $\left(n^{*}\right)$ was derived only from the flower heads that were attacked by the insects. In this study, $n^{*}$ could not be derived directly from $n f$ and ne, because collected flower heads were not kept separately. However, $n^{*}$ was assessed for the following three thistle species: C. japonicum, C. matsumurae and C. kagamontanum collected in Kanazawa. Flower heads were individually kept in cups (100 $\mathrm{mm}$ in diameter $\times 40 \mathrm{~mm}$ deep) under laboratory conditions to record the number of individuals that emerged. 


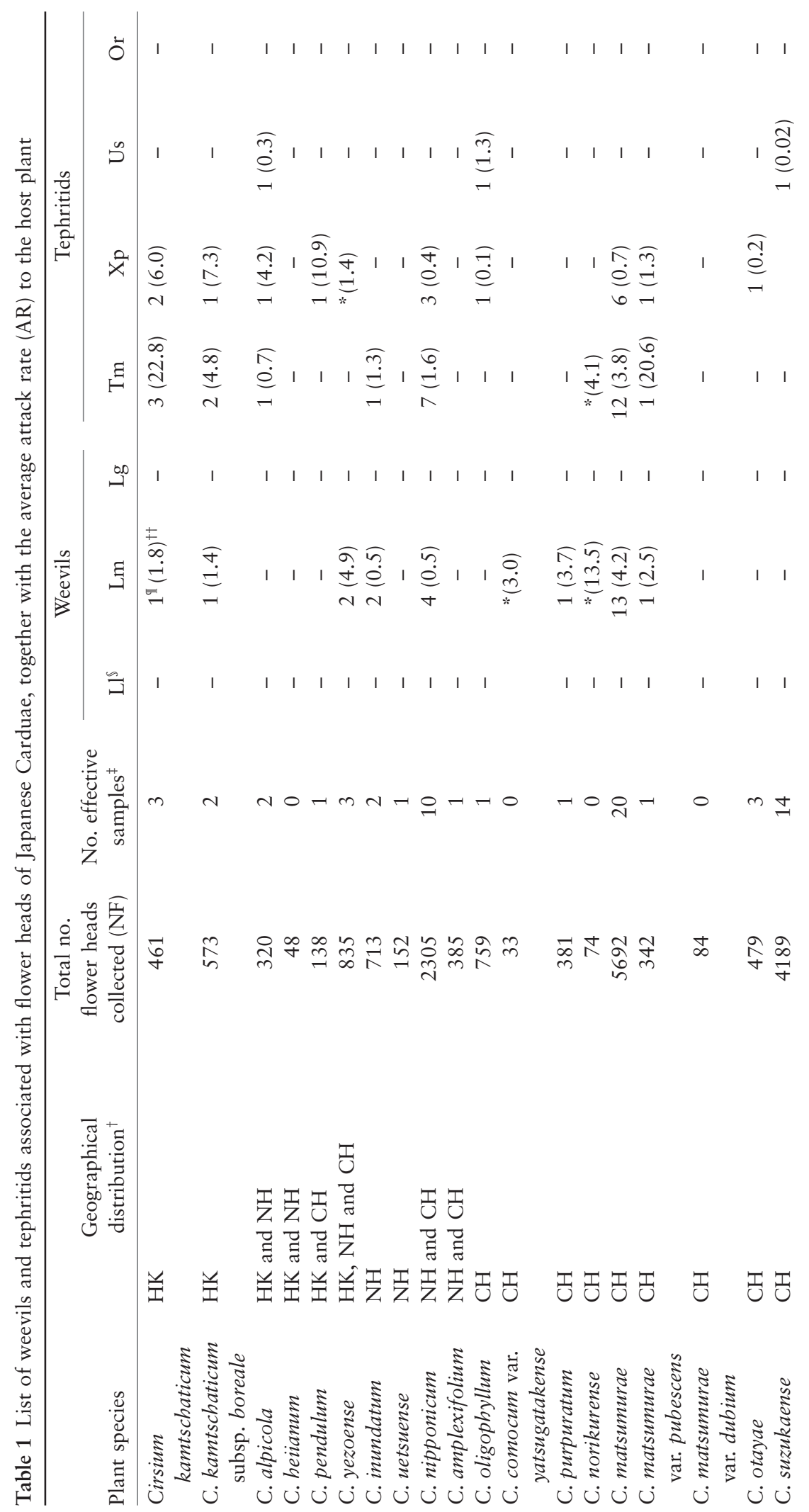




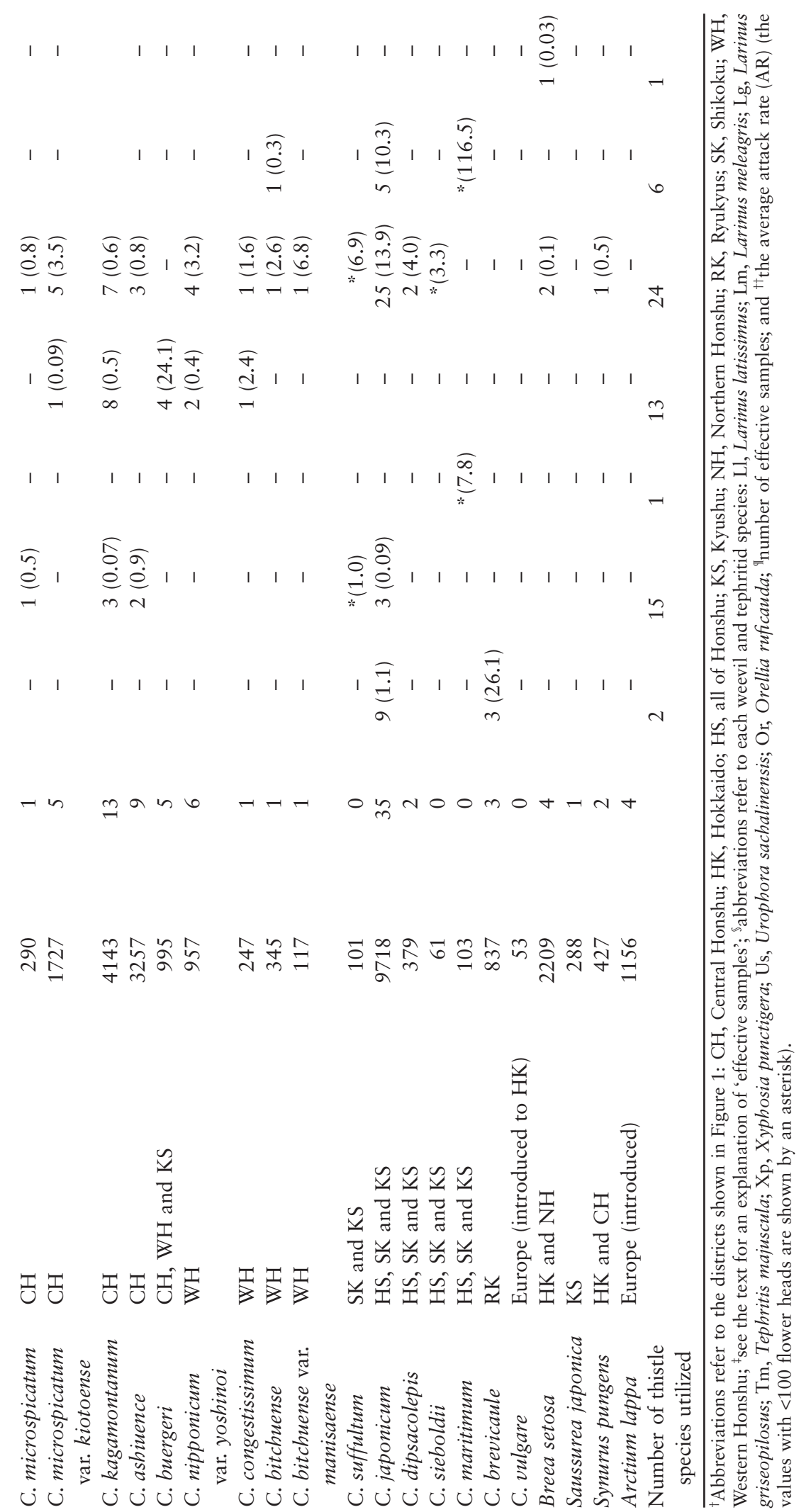




\section{Estimation of attack rate of insects}

The attack rate (AR) of weevil and tephritid species for individual samples was derived as follows:

$$
A R_{\mathrm{ij}}=\left(n e_{\mathrm{ij}} / n f_{\mathrm{j}}\right) \times 100
$$

where $A R_{\mathrm{ij}}$ is the attack rate by insect species $\mathrm{i}$ for sample $\mathrm{j}, n f_{\mathrm{j}}$ is the number of flower heads in the $\mathrm{jth}$ sample, and $n e_{\mathrm{ij}}$ is the number of individuals of insect species $i$ that emerged from sample $j$. Table 1 shows the average AR calculated for each thistle species that had effective samples (except for those specifically mentioned: see the footnote of Table 1). Table 2 shows the average AR for each insect species on the springand autumn-blooming thistles. When only one individual of species $\mathrm{i}$ emerged from a single flower head $\left(n^{*}=1\right), A R_{\mathrm{ij}}$ was exactly the same as the ratio of flower heads infested by species i; however, when $n$ individuals emerged from one flower head, the value was $n$-fold of the true ratio of damaged flower heads. In this paper, AR will be used as an approximation measure.

\section{Similarity in insect host range}

The degree of overlap of insect species $i$ and $j$ in host plant usage was examined by two indices. First, the Jaccard coefficient of community $\left(S_{\mathrm{ij}}\right)$ (Krebs 1999) was calculated for all pairs of insect species as follows:

$$
S_{i j}=a /(a+b+c)
$$

where $a$ is the number of thistle species utilized by both insect species $\mathrm{i}$ and $\mathrm{j}$, and $b$ and $c$ are numbers of thistle species used only by $\mathrm{i}$ and $\mathrm{j}$, respectively.

Second, the percentage similarity $\left(P S_{\mathrm{ij}}\right)$ (Krebs 1999) was calculated as follows:

$$
\begin{gathered}
\mathrm{PS}_{\mathrm{ij}}=\sum_{\text {min. }}\left(\mathrm{P}_{\mathrm{ix}} \mathrm{P}_{\mathrm{jx}}\right) \\
P_{\mathrm{ix}}=n_{\mathrm{ix}} / N_{\mathrm{i}}, \quad P_{\mathrm{jx}}=n_{\mathrm{jx}} / N_{\mathrm{j}}
\end{gathered}
$$

where $N_{\mathrm{i}}$ and $N_{\mathrm{j}}$ are the total number of individuals of insect species $\mathrm{i}$ and $\mathrm{j}$ emerged, respectively, and $n_{\mathrm{ix}}$ and $n_{\mathrm{j} x}$ are the number of individuals of insect species $i$ and $j$ which emerged from thistle species $x$. In this study, the number of thistle flower heads sampled was variable among the species; therefore, to derive $P_{\mathrm{ix}}$ and $P_{\mathrm{jx}}, A R_{\mathrm{ix}}$ was used for $n_{\mathrm{ix}}$ and $A R_{\mathrm{jx}}$ for $n_{\mathrm{j} x}, \sum A R_{\mathrm{ix}}$ and $\sum A R_{\mathrm{jx}}$ were used for $N_{\mathrm{i}}$ and $N_{\mathrm{j}}$, respectively.

UPGMA cluster analysis was carried out on the two similarity matrixes derived by $S_{\mathrm{ij}}$ and $P S_{\mathrm{ij}}$.

\section{RESULTS}

\section{Weevils and tephritids that emerged from thistle flower heads and their attack rate}

In this study, a total of six species - three Larinus species (Curculionidae) and three tephritid fly species - were recorded from Cirsium. More than one of these insect species was recorded from 30 Cirsium taxa collected in 111 (142 samples) of 149 sampling sites (192 samples in total). Two and one tephritid fly species were recorded from Breea and Synurus, respectively, in four (four samples) of 14 sampling sites (14 samples). Neither weevils nor tephritids were recorded from Saussurea or Arctium (Table 1). Cirsium had a richer insect fauna than other genera. Below are brief notes on host thistle species, distribution of collection sites and AR for each insect species.

\section{Family Curculionidae: genus Larinus}

\section{Larinus latissimus Roelofs}

Host plant. This weevil emerged from C. japonicum, the only spring-blooming species widespread in Honshu, Kyushu and Shikoku, and C. brevicaule, which is also a spring-blooming species and is locally distributed in Ryukyu (from the Amami-oshima to the Sakishima islands (Kadota 1995) (Table 1). The C. brevicaule feeding population was recognized as L. latissimus kuroiwai Kono (Morimoto, pers. comm., 1995). Of the 43 samples (38 sites) of C. japonicum (Fig. 2a), this weevil species was found in central Honshu (12 samples) and also in Fukuoka Prefecture, Kyushu (one sample) (Fig. 3a). In central Honshu, the species emerged from the samples collected on both the Japan Sea side (Ishikawa Prefecture, six samples from three sites) and the Pacific Ocean side (Mie Prefecture, five samples from five sites), but it was not found in the samples (13 samples from 12 sites) collected in the inland area between Fukui and the northern part of Lake Biwa (Figs 2a,3a). In C. brevicaule, the weevil emerged from all three samples collected in Okinawa Prefecture (Fig. 3a).

Attack rate. The average value of $\mathrm{AR}$ was low in C. japonicum (1.1) and high in C. brevicaule (26.1) (Table 1), although AR of C.japonicum was high for one sample from Mie and in Fukuoka Prefecture: 11.3 and 11.9 , respectively.

Remarks. In central Honshu, the fact that springblooming C. japonicum was the only host and also the fact that the adult weevils emerged at the end of the flowering season from early to late July suggests that 
Weevils and tephritids in Cirsium flower heads

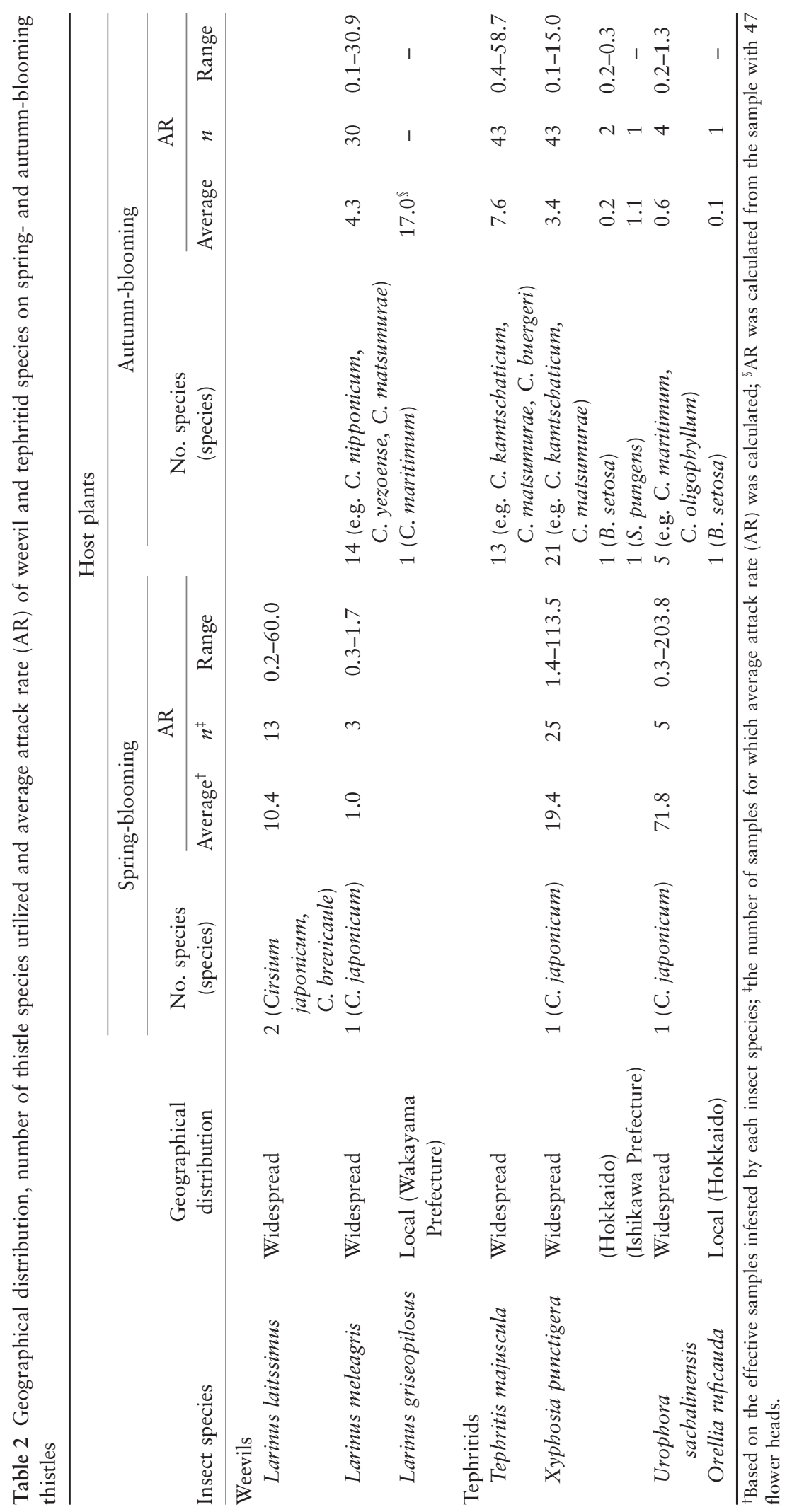


this weevil is univoltine and overwinters as adults. The $n^{*}$ was 1 or 2 (average 1.2) in C. japonicum (Table 3). In addition, one or two larvae or pupae were found from 69 of 150 flower heads of C. brevicaule dissected.

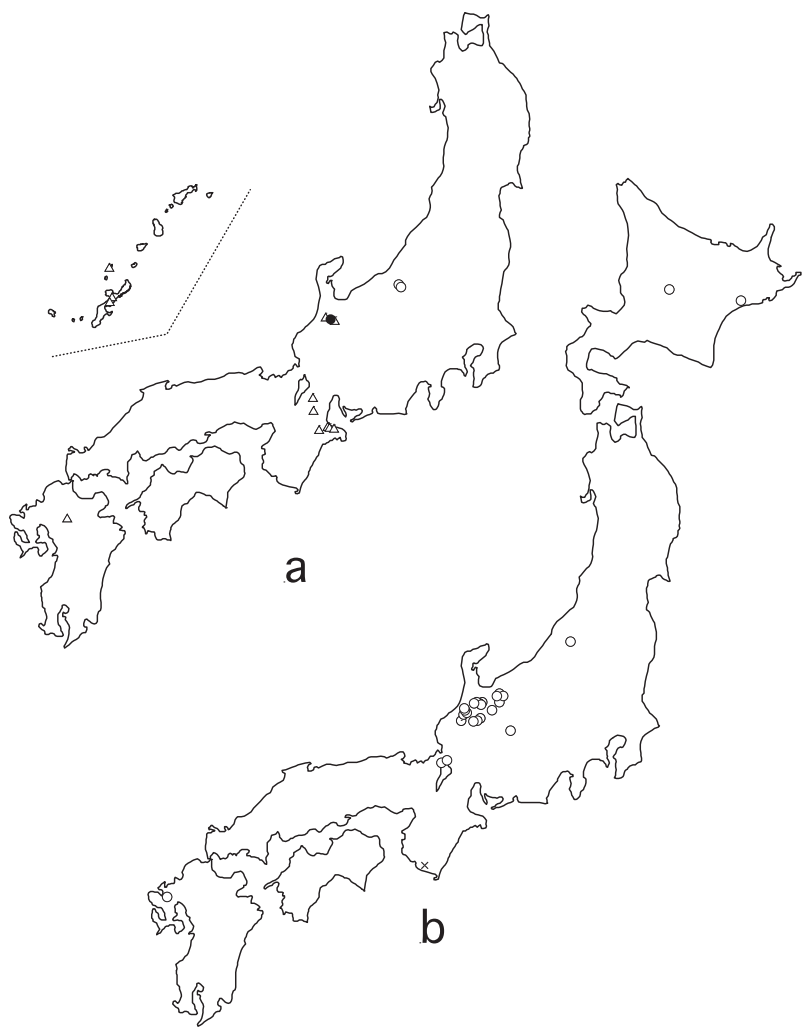

Figure 3 Distribution maps of three Japanese species of the genus Larinus for (a) spring-blooming thistles and (b) autumnblooming thistles. $\triangle$, L. latissimus; $\bigcirc$, L. meleagris; $\times$, L. griseopilosus; , L. latissimus and L. meleagris (coemerged from the same sample).

\section{Larinus meleagris Petri}

Host plant. This weevil species emerged from both spring-blooming C. japonicum and 14 autumn-blooming Cirsium taxa (Table 1). On C. japonicum, the weevil emerged in a small number from only three samples collected on the Japan Sea side of central Honshu (Niigata Prefecture, two samples from two sites; Ishikawa Prefecture, one sample) (Fig. 3a). In contrast, on autumn-blooming thistle species, the weevil emerged from a total of 42 samples collected from 30 sites, which were sporadically distributed from Hokkaido to Kyushu (Fig. 3b).

Attack rate. AR was very low in C. japonicum samples (0.3-1.7) (Table 2). In autumn-blooming thistles, the average AR was also low (4.3) (Table 2), with high values for some samples; for example, 15.7 and 30.9 in C. matsumurae samples and 10.2 in a C. yezoense sample collected in Ishikawa Prefecture.

Remarks. In central Honshu, the distribution of this weevil seemed biased on the Japan Sea side, based on the fact that thistles growing on the Pacific Ocean side, for example C. suzukaense collected in Mie Prefecture and C. maritimum Makino in Wakayama Prefecture, were not utilized by the weevil.

The weevil mostly utilized autumn-blooming thistles and it also used the spring-blooming thistle, but with a very low frequency. Of seven sites where we collected both spring- (13 samples) and autumn-blooming (26 samples) thistles, at six sites, the weevil emerged from either one of the seasonal blooming thistles, suggesting univoltinism depending on only one seasonal thistle. However, at the remaining site, it emerged from both spring- and autumn-blooming thistles, indicating the possibility of bivoltinism, depending on both seasonal thistles. The voltinism of this species is thus still

Table 3 Number of individuals of weevils and tephritid flies emerged from a flower head $\left(n^{*}\right)$

\begin{tabular}{llccc}
\hline & \multicolumn{2}{c}{ No. individuals } & & \\
\cline { 2 - 3 } Insect species & Average & Range & $n^{\dagger}$ & Examined host \\
\hline Weevils & 1.2 & & 18 & Cirsium japonicum \\
$\quad$ Larinus latissimus & 1 & $1-2$ & 90 & C. matsumurae \\
$\quad$ Larinus meleagris & 1 & 1 & 2 & C. kagamontanum \\
Tephritids & 1 & 1 & 39 & C. matsumurae \\
$\quad$ Tephritis majuscula & 1 & 1 & 9 & C. kagamontanum \\
$\quad 1.3$ & 1 & 378 & C. japonicum \\
$\quad$ Xyphosia punctigera & 1.2 & $1-5$ & 13 & C. matsumurae \\
\hline
\end{tabular}

${ }^{\dagger}$ Number of flower heads from which adults emerged (see text). 
unknown. On autumn-blooming thistles, the adults emerged from October to early November, so that this species seems to overwinter as adults. The $n^{*}$ was 1 in C. matsumurae and C. kagamontanum (Table 3).

In Japan, L. latissimus and L. meleagris partitioned hosts by season: one used a spring-blooming thistle species and the other an autumn-blooming one. In Europe and North America, seasonal segregation in host plant usage has not been reported.

\section{Larinus griseopilosus Roelofs}

Host plant. This species emerged only from C. maritimum collected in Wakayama Prefecture (one site, one sample) (Table 1; Fig. 3b).

Attack rate. Eight L. griseopilosus adults emerged from 47 flower heads $(\mathrm{AR}=17.0)$ (Table 2).

\section{Family Tephritidae}

\section{Tephritis majuscula Hering and Ito}

Host plant. The fly emerged from 13 autumn-blooming Cirsium taxa growing in Hokkaido (C. kamtschaticum. Ledeb. ex DC.), central Honshu (e.g. C. nipponicum, C. matsumurae and C. kagamontanum), Kyushu (C. buergeri Miq.) and other sites to a total of 49 samples from 39 sites (Table 1; Fig. 4b).

Attack rate. AR was frequently high: 14.8-30.8 for three C. kamtschaticum samples in Hokkaido; 11.7 and 24.0 for two C. matsumurae samples in Hokuriku (in addition, 16 adults emerged from one sample with 72 flower heads, $\mathrm{AR}=22.2$ ); 20.8 and 38.6 for two C. buergeri samples on the Pacific Ocean side of central Honshu (in addition, 29 adults emerged from a sample with 51 flower heads, $\mathrm{AR}=56.9$ ); and 58.7 for one C. buergeri sample in Kyushu.

Remarks. This tephritid species utilized only autumnblooming Cirsium species and adults emerged at the end of the flowering period from late October to early November, and the species seems to be univoltine and overwinter as adults. Some species of European Tephritis feed on callus (Zwölfer 1985), but T. majuscula larvae did not form a callus. Most larvae of all European Tephritis species are gregarious in flower heads, but in this study, only one adult of T. majuscula emerged from a flower head $\left(n^{*}=1\right)$ of C. matsumurae and C. kagamontanum (Table 3).

\section{Urophora sachalinensis Shiraki}

Host plant. Six Cirsium taxa, including both springblooming C. japonicum (eight samples from eight sites) and five autumn-blooming taxa (six samples from six sites) (Table 1) were used as host plant. This fly species

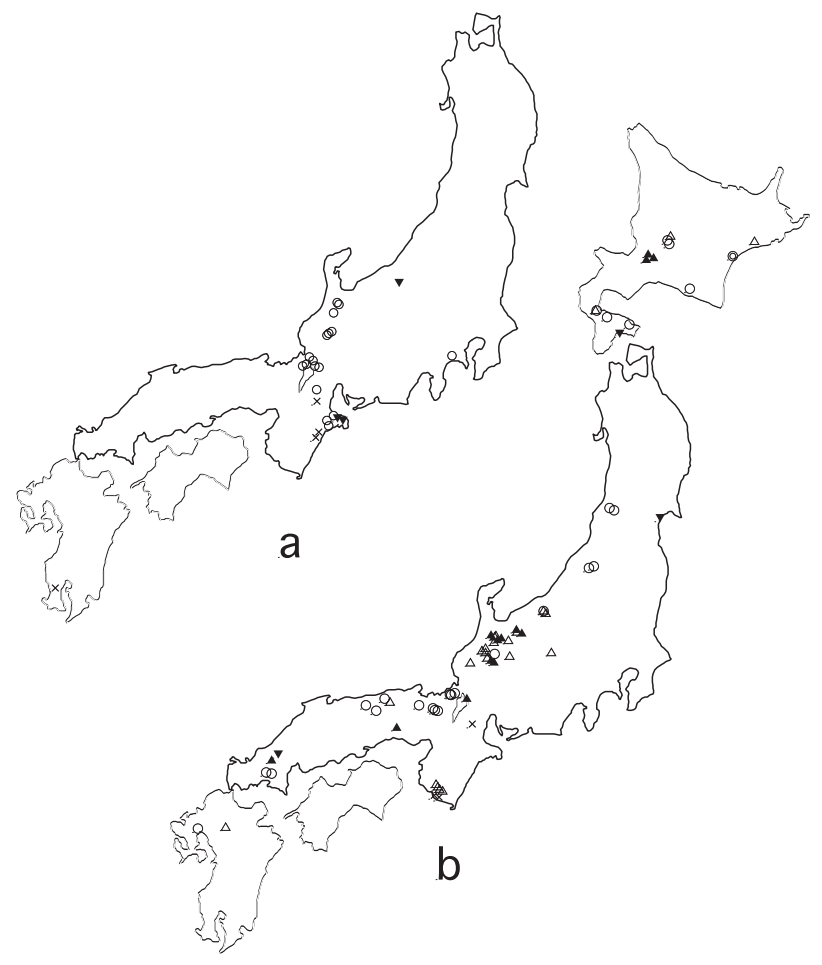

Figure 4 Distribution maps of four Japanese species of tephritids for (a) spring-blooming thistles and (b) autumn-blooming thistles. $\triangle$, Tephritis majuscula; $\bigcirc$, Xyphosia punctigera; $\times$, Urophora sachalinensis; (), Orellia ruficauda; $\nabla$, $X$. punctigera and U. sachalinensis (emerged from the same sample); $\boldsymbol{\Delta}, T$. majuscula and X. punctigera (emerged from the same sample).

was widespread from Hokkaido to Kyushu, but its occurrence was sporadic (Fig. 4a,b). On the Japan Sea side, it was not recorded from the Hokuriku or San'in districts, except in one site (Niigata Prefecture, C. japonicum), while the species was commonly collected on the Pacific Ocean side of central Honshu (six of 11 C. japonicum samples in Mie Prefecture; both of two C. maritimum samples in Wakayama Prefecture) (Fig. 4a,b).

Attack rate. AR of a few samples was extremely high on the Pacific Ocean side of central Honshu (e.g. 149.8 and 203.8 for C. japonicum collected in Mie Prefecture; 92.9 and 144.7 for C. maritimum collected in Wakayama Prefecture, where the number of flower heads was only 52 and 68 , respectively), but AR in other areas was generally low (average: 1.1; range: $0.3-1.3$ ). Remarks. This species utilized both spring- and autumn-blooming thistle species. However, all of these samples were collected from different locations. The 
voltinism of this species is to be studied. Larvae of this fly formed lignified, cup-shaped ovary-receptacle galls in flower heads, in which an average of 2.9 (SD: 3.2; range: 1-26 $(n=88)$, Mie Prefecture) cells were found, and they overwintered as mature larvae in the galls.

\section{Xyphosia punctigera Coquillett}

Host plant. This species emerged from more than one host genus, which was the only such case among the weevils and tephritids recorded in this study. It emerged from 22 Cirsium taxa (spring-blooming C. japonicum and 21 autumn-blooming taxa), Breea setosa (M. Bieb.) Kitam. and Synurus pungens (Franch. and Sav.) Kitam. (Table 1): these were distributed widely from Hokkaido to Kyushu (80 samples from 62 sites) (Table 1; Fig. 4a,b). However, the distribution in central Honshu was concentrated on the Japan Sea side, as shown partly by the fact that the species emerged neither from C. maritimum nor C. buergeri in Wakayama Prefecture, nor from C. suzukaense in Mie Prefecture (Fig. 4a,b). Attack rate. In C. japonicum, AR was frequently high (average 18.3, range 10.4-113.5 on 17 of 29 samples) (Table 2) with the highest value (113.5) in Mie Prefecture. In 21 autumn-blooming Cirsium taxa, AR was generally low (average 3.4, range 0.1-15.0) (Table 2) except for a few samples (e.g. 15.0 in C. kamtschaticum; 14.6 in C. kamtschaticum ssp. boreale (Kitam.) Kitam.; 10.9 in C. pendulum Fisch. ex DC.; and 11.0 in C. microspicatum var. kiotoense Kitam.). AR was also low in B. setosa (0.2) and S. pungens (1.1) (Table 2).
Remarks. At many sampling sites, this fly species utilized both spring-blooming C. japonicum and autumnblooming thistle species; for example, in Kanazawa it emerged from C.japonicum and autumn-blooming C. matsumurae growing nearby. This fact shows that the species is bivoltine. Adults emerged at the end of the flowering season of C. japonicum from early to late in July, and mature larvae of this species hibernated within the flower heads of autumn-blooming Cirsium hosts. The $n^{*}$ was $1-5$ (average: 1.3) (Table 3).

As mentioned above, U. sachalinensis and $X$. punctigera emerged from both spring- and autumnblooming thistle species, but these two species were rarely recorded simultaneously (one sample in Niigata Prefecture and two in Mie Prefecture on spring-blooming C. japonicum, and one sample each in Hokkaido, Miyagi and Shimane prefectures on autumn-blooming Cirsium species) (Fig. 4a,b). The former was collected mainly on the Pacific Ocean side, and the latter mainly on the Japan Sea side.

\section{Orellia ruficauda $F$.}

Only one individual emerged from one of six samples of B. setosa collected from six sites in Hokkaido. AR was 0.1 (Table 2).

\section{Similarity in insect host range \\ Jaccard coefficient of community}

The similarity matrix based on the Jaccard coefficient of community (Table 4) showed that the index was highest, 0.42 , between L. meleagris and X. punctigera, each utilizing 15 and 25 Cirsium species, respectively, and

Table 4 Similarity matrices of Jaccard coefficient and percent similarity index

\begin{tabular}{|c|c|c|c|c|c|c|}
\hline & $\begin{array}{l}\text { Larinus } \\
\text { latissimus }\end{array}$ & $\begin{array}{l}\text { Larinus } \\
\text { meleagris }\end{array}$ & $\begin{array}{c}\text { Larinus } \\
\text { griseopilosus }\end{array}$ & $\begin{array}{l}\text { Tephritis } \\
\text { majuscula }\end{array}$ & $\begin{array}{l}\text { Xyphosia } \\
\text { punctigera }\end{array}$ & $\begin{array}{c}\text { Urophora } \\
\text { sachalinensis }\end{array}$ \\
\hline \multicolumn{7}{|l|}{ Jaccard coefficient } \\
\hline L. latissimus & 1 & - & - & - & - & - \\
\hline L. meleagris & 0.06 & 1 & - & - & - & - \\
\hline L. griseopilosus & 0 & 0 & 1 & - & - & - \\
\hline T. majuscula & 0 & 0.4 & 0 & 1 & - & - \\
\hline$X$. punctigera & 0.04 & 0.42 & 0 & 0.4 & 1 & - \\
\hline U. sachalinensis & 0.14 & 0.05 & 0.17 & 0.06 & 0.17 & 1 \\
\hline \multicolumn{7}{|c|}{ Percent similarity index } \\
\hline L. latissimus & 1 & - & - & - & - & - \\
\hline L. meleagris & 0.001 & 1 & - & - & - & - \\
\hline L. griseopilosus & 0 & 0 & 1 & - & - & - \\
\hline T. majuscula & 0 & 0.23 & 0 & 1 & - & - \\
\hline X. punctigera & 0.18 & 0.14 & 0 & 0.19 & 1 & - \\
\hline U. sachalinensis & 0.07 & 0.001 & 0.91 & 0.002 & 0.08 & 1 \\
\hline
\end{tabular}


sharing 11 of these species (C. japonicum and 10 autumn-blooming thistle species). The second highest index was 0.4 for two combinations: between L. meleagris and T. majuscula (utilizing 13 autumnblooming thistle species), and between $X$. punctigera and T. majuscula, sharing eight and 10 thistle species, respectively. The third highest similarity, 0.17 , was found between U. sachalinensis, utilizing C. japonicum, C. maritimum and four other thistle species, and two insect species: first with $X$. punctigera, sharing five thistle species, including C.japonicum; and second with L. griseopilosus, recorded only from C. maritimum (Table 2).

Cluster analysis, carried out on Jaccard coefficients (Fig. 5a), indicated L.meleagris, X. punctigera and T. majuscula composed the first cluster (a-1) by sharing many autumn-blooming thistle species. Larinus latissimus, U. sachalinensis and L. griseopirosus formed the second cluster (a-2) by sharing C. japonicum (L. latissimus and U. sachalinensis) and C. maritimum (U. sachalinensis and L. griseopirosus).

(a)

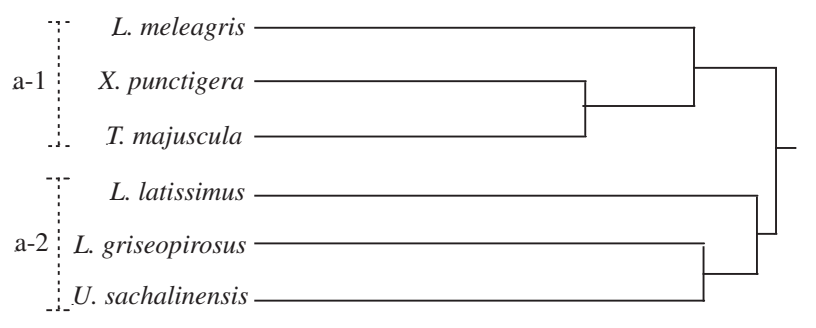

(b)
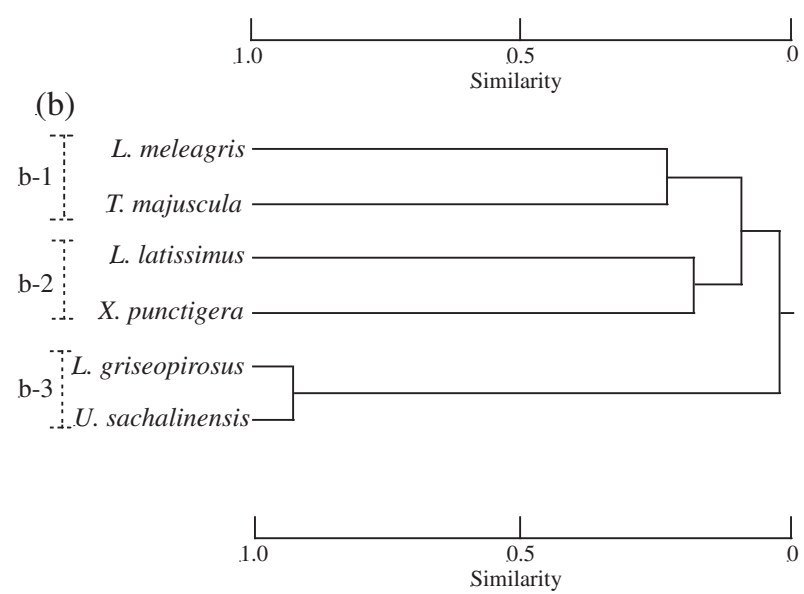

Figure 5 Cluster diagrams for host plant similarity of the insects associated with the flower head of Japanese Cirsium. Cluster analyses were carried out on the Jaccard coefficient (a) and percentage similarity (b).

\section{Percentage similarity}

The similarity matrix based on percentage similarity (Table 4) indicates that the index was highest between L. griseopilosus and U. sachalinensis (0.91), and was second highest for L. meleagris and T. majuscula, which shared eight species $(0.23)$. The third and fourth highest similarity $(0.19$ and 0.18$)$ was found in T. majuscula and $X$. punctigera (sharing 10 autumn-blooming thistle species), and L. latissimus and X.punctigera (sharing only C. japonicum), respectively.

The percentage similarity index $\left(P S_{\mathrm{ij}}\right)$, calculated on the basis of relative abundance using AR (Table 4), was somewhat different from similarity indices based on Jaccard coefficients: L. griseopilosus and U. sachalinensis had a closer relationship in percentage similarity $(0.91$, highest) than that in Jaccard coefficients $(0.17$, third highest), because they shared only C. maritimum, but their relative abundances were extremely high on this host (1 and 0.91 , respectively). The percentage similarity between L. latissimus and $X$. punctigera (0.18, fourth highest) was also higher than that calculated by Jaccard coefficients $(0.05$, ninth highest), because their relative abundances on C. japonicum, the only shared host, were high (1 and 0.18 , respectively). In contrast, the percentage similarity between L. meleagris and X.punctigera (0.14, fifth highest) was lower than that in Jaccard similarity $(0.42$, highest), because these species shared 11 thistle species, but their relative abundance was not simultaneously high for the same thistle species. For example, the relative abundance of L.meleagris was high only on C. matsumurae (0.21), but extremely low on 10 other species (0.001-0.08), and that of X. punctigera was high on C. japonicum and C. suffultum (0.18 and 0.1, respectively), but extremely low on eight other species (0.002-0.07).

Cluster analysis carried out on the percentage similarity mentioned above showed different results from that in the Jaccard coefficient analysis (Fig. 5b): L. meleagris and T.majuscula formed the first cluster (b-1), L. latissimus and X. punctigera a second cluster (b-2), and L. griseopilosus and U. sachalinensis a third (b-3).

In summary, the combination of a weevil and a tephritid (i.e. L. latissimus and X.punctigera, L. meleagris and T. majuscula or L. griseopilosus and U. sachalinensis) showed strong similarity, forming a cluster in both similarity indices, while the combination of two species in the same taxonomic group (weevilweevil or tephritid-tephritid) showed a lower host plant similarity. These facts suggest that the two species, utilizing the Cirsium flower heads in a similar way, may 
segregate the host plants through interference (or competition).

\section{DISCUSSION}

\section{Species richness of weevils and tephritid flies associated with flower heads of the Japanese Cirsium}

In the present study, we recorded three Larinus species (Curculionidae) and three tephritid fly species (Tephritis, Urophora and Xyphosia) from the flower heads of 35 taxa of Japanese Cirsium. Two other tephritid flies, Chaetostomella stigmataspis (Zwölfer 1973) and Tephritis longicauda (Sueyoshi 1998), were also recorded from Japanese Cirsium but they were not found in the present study. In total, five tephritid fly species (four genera) were recorded from Japanese Cirsium. In this study, we examined more than half of the Japanese Cirsium species. However, we collected the samples mainly from central Honshu, particularly from Hokuriku: samples from other regions were limited. Among the three Larinus species, two were widespread, but the other two were locally distributed. All three tephritid species were widespread and utilized various thistle species. We probably recorded a substantial portion of the widespread insect species, but the species with localized distribution, such as L. griseopirosus, might have been overlooked. In the future, we should examine thistles in regions other than central Honshu more extensively.

Zwölfer (1985) mentioned that the major determinants of insect diversity in Cirsium flower heads are the regional and local species richness of the host thistles and the biogeographic history of the Cardueae. Zwölfer (1965) recorded six weevil species (two genera) and 12 tephritid fly species (seven genera) from 16 Cirsium, approximately one quarter of the European Cirsium species, collected from seven countries. In North America, four tephritid fly species and no weevils were recorded (Goeden \& Ricker 1986b, 1987a,b) (Fig. 6a). The average numbers of insect species on a Cirsium species in Europe, Japan and North America were $1.8 \pm 1.1,1.0 \pm 0.7$ and 0 weevils, and $2.7 \pm 1.6$, $1.8 \pm 0.4$ and $1.6 \pm 1.4$ tephritids, respectively (Fig. $6 \mathrm{~b}$ ) (the figures for Europe were derived from Zwölfer (1965), for North America from Goeden \& Ricker (1986b, 1987a,b) and for Japan from this study). Species richness of weevils and tephritids attacking Cirsium in Japan was lower than that in Europe and higher than that in North America. This gradient in the richness of these insects is contrary to the species richness of the (a)

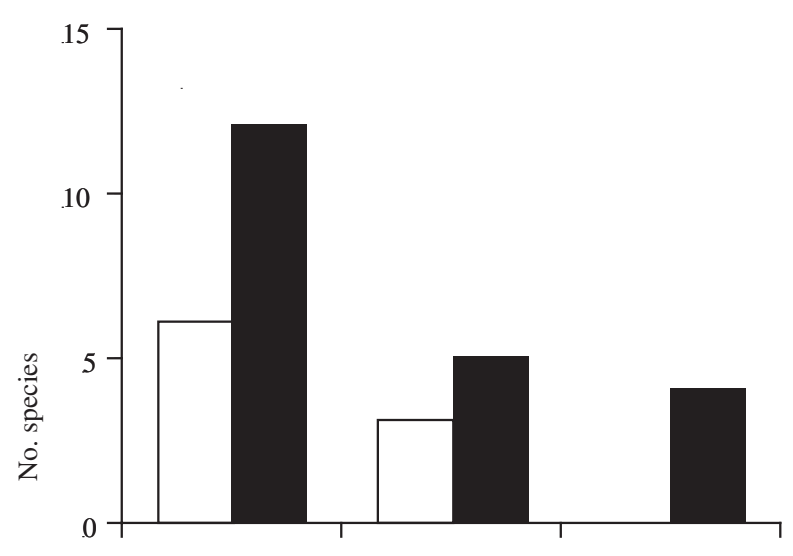

(b)

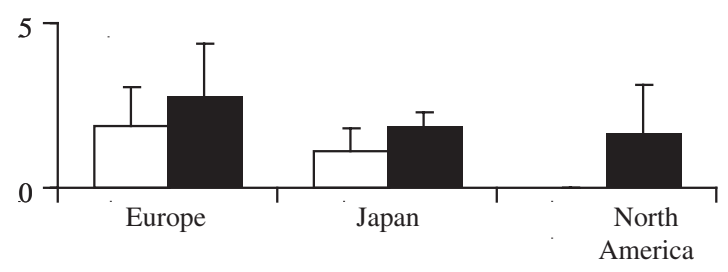

Figure 6 Number of insect species associated with the flower head of the Cirsium genus in Europe, Japan and North America. Total number of species (a) and average number of insect species per Cirsium species (b). $\square$, Weevils; $\mathbf{0}$, tephritids.

genus Cirsium, which could be explained by (i) lower species richness of the tribe Cardueae in Japan and (ii) shorter history of insect-thistle interactions than in Europe, the place of origin of the thistles.

\section{Specialization in host usage}

The degree of specialization was considered from the following two aspects: host specificity and guild structure.

In insects associated with the flower head, host range becomes narrower as the host plant-herbivore interactions advance (Zwölfer \& Romstöck-Völkl 1991). In Europe, the average number of Cirsium species utilized by a single insect species was 3.6 (SD: 2.8 ; range: $1-10$ ) in Tephritidae (12 species in seven genera) and 4.7 (SD: 3.5; range: 1-10) in weevils (six species in two genera) (derived from Zwölfer 1965). In North America, all tephritid species attack not only the genus Cirsium, but also other genera of Cardueae (Goeden \& Ricker 1986b, 1987a,b). In Japan, comparable values for Tephritidae and weevils were 13.7 species (SD: 8.0; range: 6-22) and 6.0 species (SD: 6.4; range: 1-15), 
respectively. Compared to the European species, the host range in Japan was broader in Tephritidae, but it was similar in the weevils, and both insect groups were more specialized than in North America.

In Japan, there are only two spring-blooming thistle species (C. japonicum and C. brevicaule), so that insects that reproduce only on the spring-blooming thistles can utilize up to two host species (e.g. L. latissimus utilized C. japonicum and C. brevicaule). In contrast, the autumn-blooming thistles are usually closely related, each occupying only a narrow area and being replaced successively by other species. Therefore, widespread insect species reproducing on autumn-blooming thistles can utilize many thistle species (e.g. L. meleagris utilized C. kamtschaticum and C. kamtschaticum ssp. boreale in Hokkaido, C.matsumurae and C. nipponicum in Hokuriku district and C. suffultum in Kyushu; Table 1). The exception is U. sachalinensis. It is widespread but utilized only five autumn-blooming species (Table 2). The gall-forming habit of this fly may limit its host range.

In the majority of Cirsium species in Europe, the herbivore fauna in flower heads showed a distinct niche structure with three complementary trophic strategies, namely guild structure: (i) an early attack on the closed buds of flower heads, usually combined with the formation of structural galls or callus growth on which the larvae feed; (ii) feeding on maturing or ripe achenes and receptacle without the induction of abnormal tissue growth; and (iii) oviposition after flower heads have opened or even in an early postbloom stage by polyphagous lepidopterous species with relatively mobile larvae that feed on plant tissues and develop carnivorous or cannibalistic tendencies when they come into contact with other inhabitants of the flower head (Zwölfer 1988). This study dealt with the weevils and tephritids, thus guild (iii) is not discussed here. In the majority of the European Cardueae, Zwölfer (1988) has found complete guilds with representatives of the two complementary guilds of the weevils and tephritids (41 host plant species with complete guilds, six with incomplete guilds). Our study showed that only U. sachalinensis, forming galls in six Cirsium species, belongs to guild (i), and callus tissue-feeder was lacking. The other five insect species recorded in this study belong to guild (ii). Thus guild (i) is not saturated in Japanese Cirsium. In North America, Cirsium flower heads also lack the insect guild (i) (Headrick \& Goeden 1998).

From these viewpoints, the weevils and tephritids of the Japanese Cirsium are characterized by a lower spe- cies richness and a lower degree of specialization in usage of the thistle flower heads.

\section{Further study}

In Europe, local populations of weevils and tephritids associated with thistle flower heads (e.g. T. conura) are often recognized as 'biotypes', showing a different host preference and morphological adaptation to host structure (Zwölfer \& Romstöck-Völkl 1991; RomstöckVölkl 1997). In this study, however, we noticed morphological differences according to size differences in flower heads among host species neither in the length of the tephritid ovipositor nor in that of the weevil rostrum. The morphology of the insects is to be measured quantitatively in our next study.

\section{ACKNOWLEDGMENTS}

We thank H. Zwölfer of Bayreuth University for his comments on our manuscript. Special thanks are due to the following specialists for identification and information on thistles and insects: T. Shimizu (Kanazawa University; Cardueae), S. Ito (Osaka Prefecture University; Tephritidae) and K. Morimoto (Kyushu University; Curculionidae). Our thanks are also due to K. Nakamura for his support of our field work in Kanazawa City, and to the following persons who contributed by collecting some of the thistle flower heads: N. Fujiyama, Y. Fukue, T. Fukuta, Y. Ikeda, K. Ishihara, J. Ishikawa, K. Kaihara, N. Kamata, S. Kogure, K. Kondou, K. Matsumoto, S. Mizoiri, S. Moriya, F. Nakasuji, T. Nishida, M. Oota, K. Takada, Y. Takimoto, K. Tanaka, F. Taniguchi, K. Toyama, T. Ueda and M. Yamashita. This study was part of the Hakusan Scientific Research Project for Nature Conservation sponsored by Ishikawa Prefecture, and was partly supported by a Grant-in-Aid for Scientific Research (no. 05454008) from the Ministry of Education, Culture, Sports, Science and Technology of Japan.

\section{REFERENCES}

Berube DE (1980) Interspecific competition between Urophora affinis and U. quadrifasciata (Diptera: Tephritidae) for ovipositional sites on diffuse knapweed (Centaurea diffusa: Compositae). Zeitschrift für Angewandte Entomologie 90, 299-306.

Bremer K (1994) Astaraceae, Cladistics and Classification. Timber Press, Oregon.

Briese DT, Sheppard AW, Zwölfer H, Boldt PE (1994) Structure of the phytophagous insect fauna of Onopordum 
thistles in the northern Mediterranean basin. Biological Journal of the Linnean Society 53, 231-253.

Goeden R (1974) Comparative survey of the phytophagous insect faunas of Italian thistle, Carduus pycnocephalus, in Southern California and Southern Europe relative to biological weed control. Environmental Entomology 3, 464474.

Goeden R, Ricker D (1986a) Phytophagous insect faunas of two introduced Cirsium thistles, C. Ochrocentrum and C. vulgare, in Southern California. Annals of the Entomological Society of America 79, 945-952.

Goeden R, Ricker D (1986b) Phytophagous insect fauna of the two most common native Cirsium thistles, C. californicum and C. proteanum, in Southern California. Annals of the Entomological Society of America 79, 953-962.

Goeden R, Ricker D (1987a) Phytophagous insect faunas of the native thistles, Cirsium congdonii, Cirsium occidentale, and Cirsium tioganum, in southern California. Annals of the Entomological Society of America 80, 152160.

Goeden R, Ricker D (1987b) Phytophagous insect faunas of native Cirsium thistles, C. mohavense, C. neomexicanum, and C. nidulum, in the Mojave desert of southern California. Annals of the Entomological Society of America 80, 161-175.

Headrick D, Goeden R (1998) The biology of nonfrugivorous tephritid fruit flies. Annual Review of Entomology 43, 217-241.

Kadota Y (1995) Tribe 9. Cardueae. In: Iwatsuki K, Yamazaki T, Boufford DE, Ohba H (eds) Flora of Japan Vol. IIIb Angiospermae Dicotyledoneae Sympetalae (b), pp 117164. Kodansha, Tokyo.

Kitamura S (1937) Cirsium. Compositae Japonicae, pars prima. Memoirs of the College of Science, Kyoto Imperial University, Series B 13, 1-134.

Krebs CJ (1999) Ecological Methodology, 2nd edn. AddisonWesley Longman, Menlo Park.

Redfern M (1983) Insects and Thistles. Cambridge University Press, New York.

Romstöck-Völkl M (1997) Host race formation in Tephritis conura: determinants from three trophic levels. In: Dettner K, Bauer G, Volk1 W (eds) Vertical Food Web Interactions, pp 21-38. Springer-Verlag, Berlin.

Romstöck-Völkl M, Wissel C (1989) Spatial and seasonal patterns in the egg distribution of Tephritis conura (Diptera: Tephritidae). Oikos 55, 165-174.

Small J (1919) The Origin and Development of the Compositae. Wesley, London.

Straw NA (1989a) The timing of oviposition and larval growth by two tephritid fly species in relation to host-plant development. Ecological Entomology 14, 443-454.

Straw NA (1989b) Taxonomy, attack strategies and host relations in flowerhead Tephritidae: a review. Ecological Entomology 14, 455-462.
Straw NA (1991) Resource limitation of tephritid flies on lesser burdock, Arctium minus (Hill) Bernh. (Compositae). Oecologia 86, 492-502.

Sueyoshi M (1998) A revision of the genus Tephritis Latreille (Diptera: Tephritidae) from Japan. Entomological Science 1, 115-128.

Webb DA (1976) Tribe Cardueae Cass. In: Tutin TG (ed) Frola Europaea, pp 208-275. Cambridge University Press, Cambridge.

Zwölfer H (1965) Preliminary list of phytophagous insects attacking wild Cynareae (Compositae) in Europe. Technical Bulletin of the Commonwealth Institute of Biological Control 6, 81-154.

Zwölfer H (1973) A survey for weed insects in Japan, Iran and Pakistan. Commonwealth Institute of Biological Control Report. CAB, Wallingford.

Zwölfer H (1979) Strategies and counter strategies in insect population systems competing for space and food in flower heads and plant galls. Fortschritte der Zoologie 25, 331-353.

Zwölfer H (1982) Patterns and driving forces in the evolution of plant-insect systems. In: Visser JH, Minks AK (eds) Proceedings of the V Symposium of Insect-Plant Relationships, pp 287-296. Pudoc, Wageningen.

Zwölfer H (1985) Insects and thistle heads: resource utilization and guild structure. In: Delfosse ES (ed) Proceedings of the VI International Symposium on Biological Control of Weeds, pp 407-416. Agriculture Canada, Ottawa.

Zwölfer H (1987) Species richness, species packing, and evolution in insect-plant systems. In: Schulze ED, Zwölfer $\mathrm{H}$ (eds) Ecological Studies, pp 301-319. Springer, Berlin.

Zwölfer H (1988) Evolutionary and ecological relationships of the insect fauna of thistles. Annual Review of Entomology 33, 103-122.

Zwölfer H (1994) Structure and biomass transfer in food webs: stability, fluctuations, and network control. In: Schulze ED (ed) Flux Control in Biological Systems, pp 365-419. Academic Press, London.

Zwölfer H, Brandl R (1989) Niches and size relationships in Coleoptera associated with Cardueae host plants: adaptations to resource gradients. Oecologia 78, 60-68.

Zwölfer H, Frick KE, Andres LA (1971) A study of the host plant relationships of European members of the genus Larinus (Col. Curculionidae). Technical Bulletin of the Commonwealth Institute for Biological Control 14, 97143.

Zwölfer H, Romstöck-Völkl M (1991) Biotypes and the evolution of niches in phytophagous insects on Cardueae hosts. In: Price PW, Lewinshon TM, Fernandes GW, Benson WW (eds) Plant-Animal Interactions: Evolutionary Ecology in Tropical and Temperature Regions, pp 487507. John Wiley \& Sons, New York. 